\title{
Arab Uprising 2011: Emergence of Extremism in Middle East and Its Regional Consequences
}

\author{
Munir Hussain*
}

Muhammad Kashif $\uparrow$

\begin{abstract}
Year 2011 was a renowned year in the Northern Africa and Middle East when Arab uprising rose in the remarkably important countries; Egypt, Tunisia, Bahrain, and Syria etc. After three years of Arab uprising, there is not a single country that has stable political system, democracy or peace. Egypt is under the military rule and elected president is behind bars. Syria and Iraq are suffering from severe civil war and there is a huge challenge of emerging wave of extremism in the form of ISIS. This research shows that Iran is increasing its political strength in the region. It has improved its regional muscle after plunge of Saddam government and Shiite government thereafter. Iraq is struggling for survival from state failure or disintegration. If it does so, there would be a considerable role of Shiite ethnicity and ISIS factor would also be substantial. ISIS factor will also impact on Saudi foreign policy, dealing with Sunni ethnic groups in the region and relations with the U.S.A. Current situation will also impact on courses of action by Turkey, Israel, Lebanon, Yemen and also Pakistan in South Asia. Yemen and Pakistani societies are also struggling against extremism and Pakistani extremist groups showed their common ties, their substantial and sustained support to ISIS in Iraq.
\end{abstract}

Keywords: $\quad$ Arab uprising, Middle East, revolution, geopolitics, Egyptian model, ISIS, turkey

\footnotetext{
* Author is a Assistant Professor in Khadim Ali Shah Bukhari Institute of Technology, Karachi (Pakistan). munir9876us@yahoo.com; munir@kasbit.edu.pk

$\dagger$ Author is Adjunct faculty in Khadim Ali Shah Bukhari Institute of Technology, Karachi. ,saykashif@yahoo.com
} 


\section{Background}

Perhaps nobody could imagine that self-immolation of Mohamed Bouazizi, ${ }^{1}$ a Tunisian youngman in Sidi Bouzid, Tunisia would surge the violent street protests in the country through December 2010. Not only the Tunisian streets but his death would ultimately enchain to the Tunisian president Zine El Abidine Ben Ali who was ruling the country for more than 23 years by $14^{\text {th }}$ of January. ${ }^{2}$ The flagrant fierce of Bouazizi's bereavement suddenly enwrapped neighbor when 18 days long protest exploded from 25 January 2011 and consequently President Hosni Mubarak vigorously abdicated his government. ${ }^{3}$ Arab uprising also tied up with Yamen, where protestors demanded President Ali Abdullah Saleh to resign and Abd Rabbuh Mansur Al-Hadi replaced him in February 2011. ${ }^{4}$ Tunisian and Egyptian upheaval also caused civil uprising in Bahrain in February 2011. ${ }^{5}$ Arab protest also witnessed in Syria, ${ }^{6}$ Algeria, ${ }^{7}$ Iraq,${ }^{8}$ Jordan, ${ }^{9}$ Kuwait, ${ }^{10}$ Morocco, ${ }^{11}$ Sudan,,${ }^{12}$ Lebanon, ${ }^{13}$ Mauritania, ${ }^{14}$ Oman, ${ }^{15}$ West Sahara ${ }^{16}$ and Saudi Arabia ${ }^{17}$ up to May 2011.

These protests were mainly civil in order to which they used different methods of protests including violence, burning of government and private property, civil contempt, strikes, rallies and marches. Typically protesters encountered with government authorities, pro-government militias and anti-protesters. Most of time, the protesters got violent in response to aggressive constrains.

There are some synonyms used for illustration of these events as "Arab Spring", ${ }^{18}$ Arab Awakening", 19 "Arab Uprising"20, "Arab Revolution" 21

\section{Measuring Arab Uprisings}

Arab upheavals were measured by different scholars from diverse dimensions in order to different geopolitical, social and economic conditions of affected regions. For example, Yemen's uprising may be linked to economic hardship and poverty as a reason because she is very poor Arab nation. But Tunisia and Libya where upheaval arose are upper middle income countries. So the reasons in Tunisia and Libya were different. Role of international politics or regime intervention looks clear in Libya but direct political influence was not apparent in Tunisia. Protests in Bahrain were mainly by Shiite minority but in Egypt and Tunisia people came across the governmental deprivation. Its shows that the measuring the reasons of Arab Uprising is very diverse and complex. This is the reason why this issue needs to be considered in different social, governmental and international dimensions.

For understanding these complex issues, Agha $\&$ Mallay's ${ }^{22}$ model of three tiers (mentioned as below) is useful for understanding these upheavals.

\section{Tiers of struggle}

(Please See Appendix 01)

\section{Struggle Type A: People against Regimes}

This shows the struggle of individuals against regime or government. Best example of this struggle was French revolution (1769) in which people came across the system. Those people had no political party, leadership or hierarchy of ideological base. These types of protester are very fed up, emotional, dishearten or disgraced due to which they came across the authority or system. Mostly they do not know about the direction of their protest, supporters of their cause and even confidence on their actions. They do this because of humiliation, intense deprivation and violation of their basic rights.

In the case of Arab uprising one can witness the direct clash of people against regimes. In the case of Tunisia, self-immolation of Buazizi on 17 December 2010 was a mix to economic hardship of a common man with humiliation of basic rights. It was a symbolic start of Arab uprising those are 
spontaneous but inclusion of the Tunisian General Labor Union (UGTT) and other professional associations played an important role in integrating disperse people.

\section{Authoritarianism/dictatorship}

The uprising of Egypt and Tunisia shows that these protests were mainly against authoritarian regimes which triggered the wave of transition in the Arab region. Political repression and lack of basic freedoms played an important role to bring protesters towards road march, rallies and civil conflicts. Ben Ali ruled in Tunisia for 23 years and Mubarak for 30 years. Most of Arab nation states are suffering from lack of freedom of speech; suppress opposition, lack of democracy and governmental influence on public expressions. The dominant position of the monarchy, authority or army (in the case of Egypt) followed that overthrow of governments in Tunisia and Egypt.

This was shown or replicated in the enchantments and slogan of the uprisings, which shows that in those protests there was no direct issue on an explicit political or religious program. On the other hand those protests were basically against the regime, system, corruption, inflation, high food prices, and low wages. It enabled those protests to uphold cohesion, cooperation and rally of mass support.

The result of Tunisian and Egyptian was also remarkably same. Both revolutions began as impulsive protests structured by lower middle class youth those were familiar with the social media including Facebook, Twitter and YouTube to organize and broadcast their communication. One drop of water became a flood in which people were stipulated for regime change. Those mass protests were mainly peaceful in their natures which were highlighted without having clear leadership or political agenda.

Those authoritative regimes were mainly depended on their networks of secret police (mukhabarat) and thugs (baltajiya) for maintaining their control on the public. ${ }^{23}$ And it was seemingly unattainable to make a positive change within same structure that was a primary reason why those protest came into existence for removing irony of Arab political system. This was also a motive according to which those mechanisms were simply eradicated by people. The Arabic word intifada means civil uprising that best conveys the focusing point of thousands of Arab people who showed their fear with regimes and authoritative systems and revolutionize their motives to make a change.

\section{Socio-Economic dimension}

Economic hardship was a reason making people violent. In Tunisia, where these uprisings began, officially accepted unemployment rate was 14 percent $^{24}$ and real rate was significantly very higher. After Buazizi's death, mostly protesters were unemployed people, street vendors, teachers, bus drivers and students who joined the mobilizations against the regime. The movement was mainly to remove the president and dictator's led government but increasing food prices and unemployment were remain important issues. In the case of Egypt, poverty level is 20 percent and only 28 percent population has household income. ${ }^{25}$

Poverty and Destitution are two generic economic reasons for people to protest against the regime. ${ }^{26}$ These socio-economic problems seem clearly in the case of Yemen and Jordan. 


\section{Struggle type B: People against people}

This type of struggle includes the clash among different political groups representing people. These groups could be political parties, military inertia, social or economic elites, and/or tribal chiefs. This type of struggle prohibited or less tolerated oppositions such as exiled leadership, parties and personalities can be included.

In the case of Libya and Syria, different armed groups were emerged in order to lean with various motivations. Most of them were politically organized as compare to general protestors of Tunisia or Egypt where enthusiasm or innocence of the protest was much clear. Undoubtedly, the reason for those armed group was also the regime change but their motives were unsentimental and dealing with raw power politics. ${ }^{27}$

In Yemen, the protestors faced anxious conditions by organized opposition parties and traitors of regime. It was witnessed that after protests against regime there were counter protests emerged by pro-government. Initial protests were against corruption, unemployment and economic problem but those changed into the removal of President Ali Abdulla Saleh. After an election the power has been transferred to vice president Abd Rabbuh Mansur Al-Hadi. Al-Hadi will look after a new constitution to be drafted. Other than Saleh there is no such transition of systems and procedures.

\section{Sectarian dimension}

Other than Tunisia and Egypt, some Arab countries faced uprising on the basis of sectarianism. Syria and Bahrain are major examples of sectarian conflicts. There are 74 percent Sunni Muslims and 11 percent Alawite (a sect of Shi'a Islam) Muslims in Syria. ${ }^{28}$ President Bashar al-Assad is belonged to the Alawite sect. Opposition claims that all the powers of government are concentrated in the hands of president, his family and privileged Alawite community. Kurdish minority (around 10-15 percent of the population) has also been claimed for repression by government authorities. Since anti-regime protests started in March 2011, just after Tunisian and Egyptian uprisings, the Syrian regime aimed to suppress the Sunni majority in which the opposition is supported by most Syrian minorities.

Second Example is Bahrain, where minority of Sunni Muslims (30 percent) is ruling over Shia majority (around 70 percent) ${ }^{29}$ Bahrain is also a peculiar sectarian structure where a great deal of sectarian dimension is remain exist. Ruling dynasty has close relations with Saudi Arabia that is proclaimed a 'Wahhabi' state that is ideologically different from Shia. On the other hand, most of opposition leaders are shia. This is a reason why ruling power portrays the Bahraini Shia opposition as Iranian agents that has been an old trick. ${ }^{30}$

\section{Struggle Type C: Regimes against other regimes}

Sometimes any international or regional regime influences or anchors within any regime. This type of influence is adopted for strategic balance of power or regional dominance. In Arab spring, the role of Saudi Arabia is an example of regime interference in Bahrain. Al-Khalifa dynasty has close ties with the Saudi Arabia due to both de facto economic and in front of restive population dependence. ${ }^{31}$ During Bahraini uprising, Al-Khalifa asked Saudi Arabia for military intervention and Saudi army came to rescue because they believed that Bahraini uprising may spread throughout rich Arab region including United Arab Emirate and even Saudi Arabia.

The role of NATO in helping anti Qaddafi forces to rebellions is also an example to regime influence into another regime. On $19^{\text {th }}$ March 2011 the United Nations Security Council approved Resolution 1973 that became a cause to multi-state military coalition for intervention in Libya. In the beginning of intervention the USA, UK, Canada, France, Denmark, Norway, Spain, Italy and Qatar took part in intervention that expended to nineteen states under the umbrella of NATO. 
There were viable and visible associations of other states in the countries of uprising. Saudi and Iranian enmity was apparent in Bahrain, Syria and Yemen. Turkey had already established close economic relations with Libya and Syria but after Arab Spring showed pro-democratic ties with these countries and insisted multilateral efforts against Syrian regime in UN and Arab League. ${ }^{32}$ Turkey was confused to fully support Syrian opposition due to Assad's connections with Tehran and to Iraq due to Kurdish connection.

More importantly, the role of US was obvious in Libya with the reference to Qaddafi but its involvement with the Tunisian and Egyptian uprising was without a clear sense of purpose. This was reason why US showed her side with protestors with the reluctance of past affiliation with Husni Mubarak. Second reason for U.S reluctance to support in the Egypt was the fame of Muslim Brotherhood in the society that could restore the political system and truly in 2012's presidential election Mohammad Morsi of Muslim Brotherhood took political lead and became the president on $30^{\text {th }}$ June 2012 but his government was come into its end by a military take over on $3^{\text {rd }}$ July 2013.

\section{Middle East in 2014}

Arab Spring has converted to Arab political instability now. Egypt has relapsed to military dictatorship; Libya is suffering from a political chaos, Syria and Iraq have turned into sever sectarian civil war. ISIS militants have announced the creation of Islamic State in Iraq, its chief Abu Bakr alBaghdadi declared himself as the Caliph and they have declared holy war against Shiits, Kurds, and Western powers.

The Middle East has come up with diverse geographic and political activities. Hundreds of political parties have emerged, numbers of media channels and newspapers have been launched, and civil society groups are active in the region. Particularly in Egypt and Tunisia, these two divisions are clearly evident. But other part of coin is full of fragmented, extreme, and fluid political landscape. Middle Eastern societies are apparently divided into two clear divisions; extremists and seculars. There was a prolonged vacuum of democratic and political autonomy in the region that has converted to a political instability.

Currently, the Middle East is afflicted by conflicts, tensions, sectarianism, civil war, bloodsheds and hatred. Anti-government rebels have been victorious in Libyan conflict due to NATO and Arab states' intervention. Syrian uprising has switched to a brutal civil war. Shiite/Sunni sectarian civil wars are evident in Syria, Iraq and Jordan.

Economic factor was also a catalyzer of Arab spring but now condition of economic uncertainty is higher than 2011. Optimists of Arab uprising were expecting a rebirth of economic activity in the region but removing decades-long dictators could not change the fate of people as common men are remain far away from witnessing substantial economic reforms and societal improvements.

Pizzi (2014) believes that emerging extremism is a fruit of public unrests against weak politics of rulers of Jordan and Lebanon. ${ }^{33}$ This argument is related to showing correlation between bad governance and emergence of extremism.

\section{Regional Impacts}

\section{Iraq}

Future of Iraq looks chaotic. The civil war in Iraq is for hegemony of single ethnic or sectarian groups and this is apparently very difficult to unite all of them in a single ethno-sectarian domain. Same problem was faced by Saddam's regime when all power were concentrated in a Sunni ethnicity that 
undergone the unrest in Shiites. There is also an idea of Kurds, Shiites and Sunnis federalism and it looks interestingly adoptable after witnessing pro-Saddam electoral and constitutional reforms as a result of a culture of compromise. Its shows that people-to-people struggle would be more feasible and adoptable for Iraqi society but there is also another barrier of Sunni Arab parties those may feel themselves the losers as compare to Shiite and Kurds in the new Iraq. Furthermore, there is a noteworthy viewpoint in Sunnis that U.S. invasion decreased their influence in the country. This viewpoint is an Eden for extremists particularly for ISIS so regime-against-people struggle would not a good solution.

\section{Iran}

There is no Saddam Hussein in Iraq who was a big rival of Iran rather Iraq is governing by Shiite prime minister so no doubt Iranian influence is increased in the region. Furthermore, the emergence of ISIS and for clearing up this threat Iraqi government is willing to cooperate with Iran that also increases its importance and influence. There are Iranian influences on Hezbollah that is also evident that Iran is continuously increasing its reputation as an influencing regional partner. From Gulf War to U.S-led Iraqi invasion Iran is constantly increasing influence in the region and expectedly it will be simultaneously increasing in the future as well unless ISIS would be controlled. Amazingly two decades long rivals the U.S.A and Iran have a common enemy, the ISIS. Apparently they are not willing to be allies but threat of ISIS can bring them together. If it does happen, it will impact on Iranian hegemony in the region. Another complex situation is in Syria. Assad government in Syria is Shiite and the U.S. administration is willing to wipe out his government. This situation also supports Iranian factor in Syria that can also increase its influence in the region. All of these factors show that the situation in the Middle East will be in favor of Iran and all conditions are helping Iran to increase its foreign and regional strength.

\section{Syria}

According to BBC, Syrian civil war has taken more than one hundred lives in past three years. This brutal conflict impacts around all neighborhoods where more or less nine million people suffered from forced migration. ${ }^{34}$

Hitherto, the U.S.A. is targeting ISIS in Syrian town Kobani by air strikes and dropping weapons for Kurdish fighters against ISIS. ${ }^{35}$ Kobani is situated on the border of Syria and Turkey. Its means this conflict is also considerable for Turkey as well.

The future of Syria would be complex. Alawite's government and rebellion conflict and U.S. air strikes have two different directions. Alawite's government and the U.S.A. are against each other but they both feel ISIS as a common threat on the other hand Alawite's government and ISIS both proclaim the U.S.A. as an enemy. Apparently if ISIS increases strength in the Middle East, it would bring the U.S and Assad's government closer. Alternatively, if the U.S.A dominates the ISIS, it will increase the distance between U.S.A and Assad, as well as with Iran.

\section{Saudi Arabia}

Saudi foreign policy is in crucial condition. It has been supported and involved in expending Sunni ties around Middle East for decades. It has also been proclaimed as promoter of radical Islam and extremism in the region that used Islamic extremism as a strategic tool during Afghan jihad. Saudi officials forcibly deny their substantial and sustained support to any radical militants including ISIS and show enthusiasm to control and abolish the extremism for touching the Saudi soil. Recently, on

an American request, Saudi Arabia has agreed to provide training base for moderate Syrian 
opposition fighters against ISIS. ${ }^{36}$ Saudi Arabia is worried in different facets of threat; the rise of Iranian dominance and increasing power of Shiite Muslim Allies. Second dilemma is resurgence of Sunni extremism by ISIS that is expanding its wings in the region. The future of Saudi Arabia can also be understood with the U.S.-Saudi ties and these relations might be reconsidered if Iran or ISIS increases strength in the region.

\section{Conclusion}

After three years of Arab uprising, there is not a single country that has stable political system, democracy or peace. Egypt is under the military rule and elected president is behind bars. Syria and Iraq are suffering from severe civil war and there is a huge challenge of emerging wave of extremism in the form of ISIS.

This research shows that Iran is increasing its political strength in the region. It has improved its regional muscle after plunge of Saddam government and Shiite government thereafter. Iraq is struggling for survival from state failure or disintegration. If it does so, there would be a considerable role of Shiite ethnicity and ISIS factor would also be substantial. ISIS factor will also impact on Saudi foreign policy, dealing with Sunni ethnic groups in the region and relations with the U.S.A.

Current situation will also impact on courses of action by Turkey, Israel, Lebanon, Yemen and also Pakistan in South Asia. Yemen and Pakistani societies are also struggling against extremism and Pakistani extremist groups showed their common ties, their substantial and sustained support to ISIS in Iraq.

There are diverse solutions for controlling current wave of extremism in Middle East. Military intervention or regime-to-regime fight by the U.S.A., UK or any regional state including Saudi Arabia and Iran would not be a good solution. There are some feasible political solutions in which governments can play minor role rather societal changes and it would be a good option because real revolution is not starts from streets but from minds and hearts. Ethno-sectarian differences are parts of Middle Eastern soil but helping one ethnic group for dominating other is a false practice since Afghan jihad during 1980s. It only created extremism in the form of Taliban, Al-Qaida and now ISIS. Building civic institutions, helping governments for social rehabilitations would be a good solution but it has been a least important mode of operation by influential powers.

\section{Notes}

\footnotetext{
1 New York Time, January 21, 2011. Accessed by http://www.nytimes.com/2011/01/22/world/africa/22sidi.html?_r=1\&pagewanted=2\&src=twrhp

$2 \quad$ Aljazeera, January $\quad 15, \quad 2011 . \quad$ Accessed by http://www.aljazeera.com/news/africa/2011/01/20111153616298850.html

3 http://articles.cnn.com/2011-01-28/opinion/shaikh.egypt.protests_1_rami-khouri-today-s-arab-arabrevolution?_s=PM:OPINION

${ }^{4}$ Bakri, Nada; Goodman, J. David (28 January 2011). "Thousands in Yemen Protest Against the Government". The New York Times, Accessed by http://www.nytimes.com/2011/01/28/world/middleeast/28yemen.html

${ }^{5}$ Pichter, Frederick, (14 February, 2011). "Protester killed in Bahrain: Day of Rage". The Reuters accessed by http://uk.reuters.com/article/2011/02/14/uk-bahrain-protests-idUKTRE71D1G520110214
} 
${ }^{6}$ Keolbl, Susanne (28 March 2011) 'It Will Not Stop': Syrian Uprising Continues Despite Crackdown". Der Spiegel. 28 March 2011. Accessed by http://www.spiegel.de/international/world/it-will-not-stop-syrianuprising-continues-despite-crackdown-a-753517.html

7 "Algeria protest draws thousands". CBC News. 12 February 2011. Archived from the original on 12 May 2011. http://www.cbc.ca/news/world/story/2011/02/12/algeria.html.

| $36{ }^{8}$ McCrummen, Stephanie (25 February 2011). "13 killed in Iraq's 'Day of Rage' protests". The Washington Post (Baghdad). http://www.washingtonpost.com/wp-dyn/content/article/2011/02/24/AR2011022403117.html.

9 "Thousands protest in Jordan". Al Jazeera. 28 January 2011. http://www.aljazeera.com/news/middleeast/2011/01/2011128125157509196.html.

10 "Kuwaiti stateless protest for third day". Middle East Online. 20 February 2011. http://www.middle-eastonline.com/english/?id=44476.

11 "Morocco King on holiday as people consider revolt". Afrol. 30 January 2011. http://www.afrol.com/articles/37175.

12 "Sudan opposition leader arrested". Press TV. 19 January 2011. http://www.presstv.ir/detail/160998.html.

13 "Lebanon: Protests against Sectarian Political System". Reuters Africa. Reuters. 27 February 2011. http://af.reuters.com/article/egyptNews/idAFLDE71Q08L20110227.

14 "Mauritania police crush protest - doctors announce strike". Radio Netherlands Worldwide, 9 March 2011. http://www.rnw.nl/africa/article/mauritania-police-crush-protest-doctors-announce-strike.

15 Vaidya, Sunil (27 February 2011). "One dead, dozen injured as Oman protest turns ugly". Gulf News. http://gulfnews.com/news/gulf/oman/one-dead-dozen-injured-as-oman-protest-turns-ugly-1.768789.

16 "Man dies after setting himself on fire in Saudi Arabia". BBC News. 23 January 2011. Archived from the original on 25 January 2011. http://www.bbc.co.uk/news/world-middle-east-12260465.

17 "New clashes in occupied Western Sahara" Afrol. 27 February 2011. Archived from the original on 7 July 2011. http://www.afrol.com/articles/37450.

${ }_{18}^{18}$ BBC News, (2 February 2011). http://www.bbc.co.uk/news/world-middle-east-12339521

19 Aljazeera, (22 February, 2011). http://www.aljazeera.com/indepth/spotlight/2011/02/2011222121213770475.html

${ }^{20}$ Lalami, Laila, (17 February 2011) "Arab Uprisings: What the February 20 Protests tell us abour Morocco". http://www.thenation.com/blog/158670/arab-uprisings-what-february-20-protests-tell-us-about-morocco\#

21 Shaikh, Salman (28 January, 2011). "We are witnessing today an Arab people's revolution" http://articles.cnn.com/2011-01-28/opinion/shaikh.egypt.protests_1_rami-khouri-today-s-arab-arab-

revolution?_s=PM:OPINION

${ }^{22}$ Agha, Hussein \& Malley, Robert, (29 September, 2011). "The Arab Counterrevolution" The New York Review of Books. http://www.nybooks.com/articles/archives/2011/sep/29/arab-counterrevolution/?pagin

${ }^{23}$ Hanieh, Adam, (14 February 2011), "Egypt's Uprising: Not Just a Question of Transition”, Socialist Project, E-Bulletin No. $\quad 462 . \quad$ Accessed by http://www.socialistdemocracy.org/RecentArticles/RecentEgyptsUprisingNotJustAQuestionOfTransition.html

${ }^{24}$ McNally, David, (19 January 2011), "Night in Tunisia: Riots, Strikes and a Spreading Insurgency" Global Research, The Socialist Project. Accessed by http://www.globalresearch.ca/index.php?context=va\&aid=22861

${ }^{25}$ Prins, Nomi, (4 February 2011), "The Egyptian Uprising is a response to Ruthless Global Capitalism", accessed by http://socialistworker.org/blog/critical-reading/2011/02/04/economic-roots-arab-revolt

${ }^{26}$ Breisinger, C. et al. (2011) Economics of the Arab Awakening: From Revolution to Transformation and Food Security, May 2011, Report by the International Food Policy Research Institute (IFPRI), Washington DC: IFPRI

${ }^{27}$ Agha, Hussein \& Malley, Robert, (29 September, 2011). "The Arab Counterrevolution" The New York Review of Books. http://www.nybooks.com/articles/archives/2011/sep/29/arab-counterrevolution/?pagin

28 World Directory of Minorities, (updated: October 2011). Accessed by http://www.minorityrights.org/?lid=5266\&tmpl=printpage

${ }^{29}$ Louer, Laurence, (May 2011), “A failed uprising in Bahrain”, ISS Opinion, European Union Institute for Security Studies. Accessed by http://www.iss.europa.eu/uploads/media/A_failed_uprising_in_Bahrain.pdf

${ }^{30}$ Ibid

${ }^{31}$ Ibid

${ }^{32}$ Gumuscu, Sebnem, 'Turkey's Reactions to the Arab Spring'. Yale Journal of International Affairs. Accessed by http://yalejournal.org/2012/05/turkeys-reactions-to-the-arab-spring/ 
${ }^{33}$ Michael Pizzi (2014), "Middle East's stable monarchy comes face to face with extremist threat" Aljazeera, America, July 10. Accessed: http://america.aljazeera.com/articles/2014/7/10/jordan-islamic-statethreat.html

${ }^{34} \mathrm{http} / / /$ www.bbc.com/news/world-middle-east-26116868 last updated 14/03/2014

${ }^{35}$ Eric Schmitt (2014), 'U.S. Airdrops Weapons and Supplies to Kurds Fighting in Kobani' New York Times, Oct $20^{\text {th }}$, http://www.nytimes.com/2014/10/20/world/middleeast/us-airdrops-weapons-and-supplies-to-kurdsfighting-in-kobani.html?_r=0

${ }^{36}$ Michael R. Gordon, Eric Shmitt (2014), 'Saudi Arabia Will Grant U.S. Request for Anti-ISIS Training Program' The New York Times, Sept 10. http://www.nytimes.com/2014/09/11/world/middleeast/saudi-arabiaisis.html

\section{Appendices}

\section{Table 01}

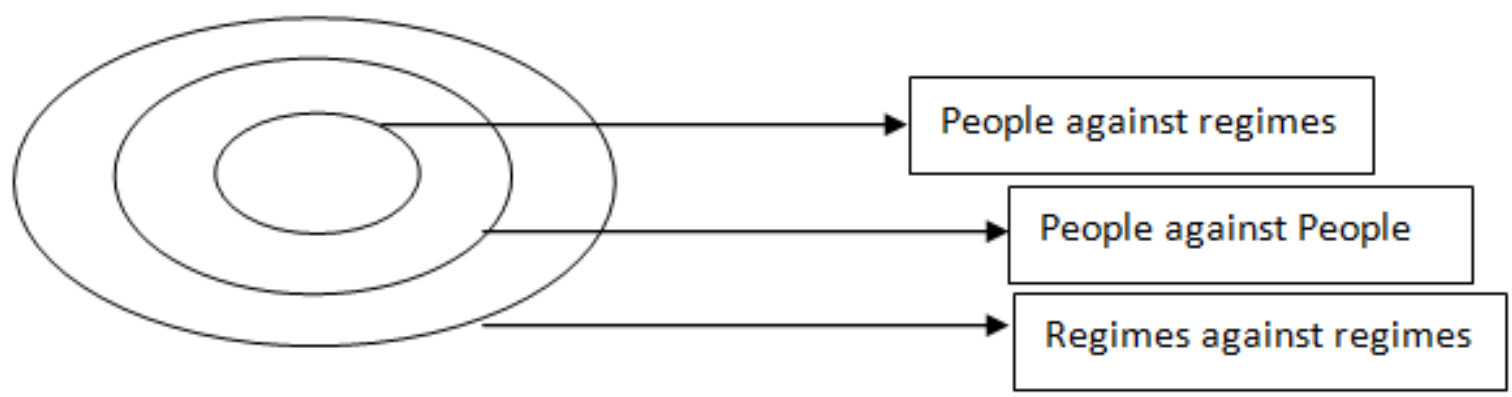

Table 02

\begin{tabular}{|c|c|c|c|c|}
\hline & Democracy $(\text { ranking })^{1}$ & $\begin{array}{l}\text { Corruption } \\
\text { (ranking) }^{2}\end{array}$ & $\begin{array}{l}\text { Press freedom } \\
\text { (rating) }\end{array}$ & HDI (ranking) ${ }^{4}$ \\
\hline Morocco & 116 & 82 & 66 & 113 \\
\hline Jordan & 117 & 50 & 63 & 82 \\
\hline Bahrain & 122 & 43 & 71 & 39 \\
\hline Algeria & 125 & 92 & 64 & 84 \\
\hline Egypt & 138 & 115 & 60 & 101 \\
\hline Tunisia & 144 & 64 & 85 & 81 \\
\hline Yemen & 146 & 144 & 80 & 133 \\
\hline Syria & 152 & 150 & 83 & 111 \\
\hline Libya & 158 & 130 & 94 & 53 \\
\hline Saudi Arabia & 160 & 83 & 83 & 55 \\
\hline
\end{tabular}

1: Democracy Index 2010, Economist Intelligence Unit

2: Corruption Perception Index 2008, Transparency International

3: Freedom of the Press report 2010, Freedom House. The level of press freedom is scored on a scale from 0 (most free) to 100 (least free).

4: Human Development Index 2010, UNDP

Source: https://graphics.eiu.com/PDF/Democracy Index 2010_web.pdf 
Munir Hussain \& Muhammad Kashif

Table 03

\begin{tabular}{|c|c|c|c|c|c|}
\hline & GDP per capita ${ }^{1}$ & GDP growth ${ }^{2}$ & Unemployment rate $\mathrm{e}^{3}$ & $\begin{array}{r}\text { Population } \\
\text { under } 25 \text { years }{ }^{4}\end{array}$ & Poverty rate ${ }^{5}$ \\
\hline Yemen & 2,900 & $6.2 \%$ & $35.0 \%$ & $65.4 \%$ & $45.2 \%$ \\
\hline Morocco & 4,670 & $3.2 \%$ & $9.8 \%$ & $47.7 \%$ & $15.0 \%$ \\
\hline Syria & 4,730 & $4.0 \%$ & $8.3 \%$ & $55.3 \%$ & $11.9 \%$ \\
\hline Jordan & 5,240 & $3.2 \%$ & $13.4 \%$ & $54.3 \%$ & $14.2 \%$ \\
\hline Egypt & 5,860 & $5.1 \%$ & $9.7 \%$ & $52.3 \%$ & $20.0 \%$ \\
\hline Algeria & 8,220 & $4.1 \%$ & $9.9 \%$ & $47.5 \%$ & $23.0 \%$ \\
\hline Tunisia & 8,620 & $3.4 \%$ & $14.0 \%$ & $42.1 \%$ & $3.8 \%$ \\
\hline Libya & 18,720 & $3.3 \%$ & n.a. & $47.4 \%$ & $30.0 \%$ \\
\hline Bahrain & 23,980 & $4.1 \%$ & $15.0 \%$ & $43.9 \%$ & n.a. \\
\hline Saudi Arabia & 22,850 & $3.8 \%$ & $10.8 \%$ & $50.8 \%$ & n.a. \\
\hline
\end{tabular}

1: GDP per capita 2010 (USD at PPP), Economist Intelligence Unit, Country Data

2: GDP 2010 (\% real change p.a.), Economist Intelligence Unit, Country Data

3: Recorded unemployment 2010, Economist Intelligence Unit, Country Data

4: Economist Online, "Mapping the Arab World", 17 February 2011

5: Percentage of population under poverty line, CIA World Factbook, latest recorded figures

Source: https://graphics.eiu.com/PDF/Democracy Index 2010 web.pdf 